\title{
LIFE AS DAMAGE: COMPENSATION OF NON-PECUNIARY DAMAGE FOR STAYING ALIVE (THE INTERPRETATION OF CIVIL LAW IN THE LIGHT OF THE CONSTITUTION)
}

This article presents a decision of the German Federal Court of Justice dealing with the question, whether life can be considered as damage which entitles to claim compensation of non-pecuniary and pecuniary damage. The question concerns the case of a person, whose state of health does not permit any communication; this person was kept alive by medical treatment, even if the person suffered from many diseases and it was evident, that the treatment will only shift the dead ahead. The court referred to the Constitution, dealing with the question, whether life can be considered in civil law as a damage.

The decision and the background will be presented as well as the two previous decisions and a comparative description of the legal questions according German and Ukrainian Law. The purpose of article is to present a decision of the German Federal Court of Justice, which - as the Court states - deals with an unprecedented issue. Due to the fact, that situations, which were the background of the Court's decision have no national limits, it is worth to present this topic also for a professional public outside Germany.

The article is based on a method of comparative analysis of constitutional and civil law. The presentation of a Court's decision and the comparative legal background has logically only the result of information for further discussion. However, the comparative presentation shows parallels on the level of the functions of rights and freedoms in a Constitution: they have the function to protect the individual against the interference of the state. But the rights and freedoms also create a system of values on the level of constitutional law which has to be considered in all spheres of national law-also in relations between private persons ruled by civil law.

Key words: life as damage, wrongful life, right to life, compensation of non-pecuniary damage, pecuniary damages, liability of doctor, medical treatment contract. 
Kateryna Kravchenko, Lawyer of the first rank of the Law Faculty of Taras Shevchenko National University of Kyiv legal_@@i.ua

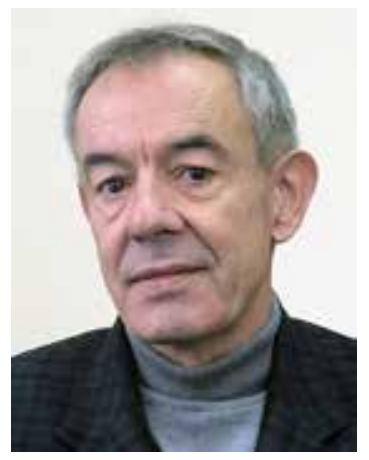

Dr. iur. Bernhard Schloer, Lecturer, Chair on Administrative Law of the Law Faculty of the Centre of German Law of Taras Shevchenko National University of Kyiv vewrmuc@gmail.com

\section{Introduction}

This article deals with the decision of the German Federal Court of Justice on a claim based on civil law. The interesting aspect of this decision is the fact, that the court used arguments from Constitutional law as the core arguments for the decision. The decision will be presented, and the aspects of the Constitution using the Ukrainian Constitution will be explained. The justification for this approach is seen in the common character of the regulations of the German and the Ukrainian Constitutions and the method, how a Constitution has to be applied.

\section{The background}

In April 2019, the highest Federal Court of Justice on civil and criminal law, the Bundesgerichtshof, had decided on a claim for compensation of non-pecuniary and pecuniary damages, which concerned the treatment of a medical doctor (Federal Court of Justice, 2019). The core question was, whether a patient of a doctor receives damages, when he stays alive because of this medical doctor's treatment, even if it is evident, that the patient's life will definitely end soon.

This case can be compared with the case on unsuccessful abortions, when the question was raised, whether the child or the child with permanent health problems is a damage for the parents.

In spite of fact that compensation is a topic related to civil (private) law, these cases demonstrate the important role of a Constitution while applying civil law. Because life is in all modern Constitutions the most important value, a human being can dispose with; for example, the Ukrainian Constitution states in article 3 , that the human being with the attributes life, health, honor and dignity is the highest value in the society, in article 27 the right to life and health is guaranteed; furthermore, according to article 27 part $1,2^{\text {nd }}$ sentence, the State has the obligation to protect life (Verkhovna Rada of Ukraine, 1996). If the Constitution states, that life is the highest value, it is consequent to make the assumption, that this qualification has to be respected also on the level of law beyond the Constitution, article 8 part 2 Constitution of Ukraine. This effect shall be presented with the example of the decision of the German civil court, because this court's arguments could also have formulated a civil court of Ukraine, see beyond IV. 2.

The plaintiff claims monetary compensation for nonpecuniary (non-material) damage due to improper life support 
through artificial nutrition and material (pecuniary) damage in the form of treatment and care expenses from the defendant (doctor) for the period from 2010 to 2011.

The previous court instances are District Court of Munich (LG München) and Higher Regional Court of Munich (OLG München).

The case was initiated by the son of the patient, because he qualifies the treatment by the medical doctor as useless efforts to keep his father alive as it was from the professional point of view definitely clear that the father will die soon.

The father, born in 1929, was increasingly dement and lived under the surveillance of a custodian (a lawyer), who decided all questions. In 2006 the father was treated in a hospital; during most of 2007 he was treated at home. Since 2008 the situation became worse, no communication with the father was possible. From beginning of 2010 till October 2011 the father suffered from fever, pneumonia and other painful problems. In October, the father was brought again to the hospital, further treatment concerned again pneumonia and on the $19^{\text {th }}$ the father went away.

The son, who inherited the right for compensation claims qualifies the father's treatment since 2010 as useless pain and a cruel life, which has to be qualified under the civil code as a damage. Furthermore, the father's custodian (a lawyer) has not been informed properly by the medical doctor; thus he could not make the appropriate decisions.

The LG München dismissed the case as unfounded (District Court Munich I, 2017). The OLG München (Oberlandesgericht München) as the previous instance had awarded a compensation of non-pecuniary damage in the amount of $40000 €$ to the plaintiff and dismissed the remainder (Higher Regional Court of Munich, 2017).

The analyses of all these decisions allows to make a conclusion that a plaintiff could be entitled to claim against a defendant for damages under $\S 280$ par. 1 of German Civil Code (CC) in conjunction with $\S 1922$ and under $\S 823$ par. 1, $\S 1922$ CC in conjunction with Art. 1 par. 1, 2 par. 1 of Basic Law of the Federal Republic of Germany (German Bundestag, 1949). Possible claims of a testator versus the defendant have passed to the plaintiff as a sole heir according to $\S 1922$ German Civil Code. Moreover, between the testator and the defendant exists an effective treatment contract since 2007.

The claim was rejected in the Munich district court (Landgericht) (District Court Munich I, 2017). The court didn't recognize any violation of the contract on medical treatment, concluded between the medical doctor and the patient, $\S 611,280$ Civil Code $^{1}$.

${ }^{1}$ Section 611 "Typical contractual duties in a service contract"

(1) By means of a service contract, a person who promises service is obliged to perform the services promised, and the other party is obliged to grant the agreed remuneration.

(2) Services of any type may be the subject matter of service contracts.

Section 280 "Damages for breach of duty"

(1) If the obligor breaches a duty arising from the obligation, the obligee may demand damages for the damage caused thereby. This does not apply if the obligor is not responsible for the breach of duty.

(2) Damages for delay in performance may be demanded by the obligee only subject to the additional requirement of section 286.

(3) Damages in lieu of performance may be demanded by the obligee only subject to the additional requirements of sections 281, 282 or 283 (German Bundestag, 2002). 
The court also rejected claims based on the violation of law according to $\S 823$ Civil Code $^{2}$. The court didn't make any remarks on the aspects of Constitutional law. However, the court states, that the general assumption of civil law "assumption of legally conformity of medical consultation" stands behind the assessment, whether life is "worth to live" and the basic law on life, because this qualification is an exclusive decision of the concerned individual. The court refers to the principle, which is part of the motivation of $\S 1901 \mathrm{a}$ Civil Code 3 : "In case, that it is impossible to evaluate the patient's will, even using all available sources, concerning the continuation or termination of the medical treatment, the supreme value of life requests a decision based on the supremacy of life". The court didn't see any violation of the doctor's duty according $\S 1901 \mathrm{a}$ and $1901 \mathrm{~b}^{4}$. The claim was refused and the plaintiff requested a review by the higher regional court.

In contrary to the district court (Landgericht), the higher regional court(Oberlandesgericht) decided in favor of the plaintiff (Higher Regional Court of Munich, 2017). The court states

${ }^{2}$ Section 823 "Liability in damages"

(1) A person who, intentionally or negligently, unlawfully injures the life, body, health, freedom, property or another right of another person is liable to make compensation to the other party for the damage arising from this.

(2) The same duty is held by a person who commits a breach of a statute that is intended to protect another person. If, according to the contents of the statute, it may also be breached without fault, then liability to compensation only exists in the case of fault (German Bundestag, 2002).

3 Section 1901a "Living will"

(1) If a person of full age who is able to consent has determined in writing, for the event of his becoming unable to consent, whether he consents to or prohibits specific tests of his state of health, treatment or medical interventions not yet directly immanent at the time of determination (living will), the custodian must examine whether these determinations correspond to the current living and treatment situation. If this is the case, the custodian must see to it that the will of the person under custodianship is done. A living will may be revoked at any time without a specific form.

(2) If there is no living will, or if the determinations of a living will do not correspond to the current life and treatment situation, the custodian must determine the wishes with regard to treatment or the presumed will of the person under custodianship, and decide on this basis whether he consents to or prohibits a medical treatment pursuant to subsection (1). The presumed will must be ascertained on the basis of concrete indications. Consideration must be given, in particular, to previous oral or written statements, ethical or religious convictions and other personal values of the person under custodianship.

(3) Subsections (1) and (2) apply regardless of the nature and stage of any illness of the person under custodianship.

(4) No one may be obliged to establish a living will. The conclusion of a contract may not be made contingent on the establishment or submission of a living will.

(5) Subsections (1) to (3) apply to authorized representatives with the necessary modifications (German Bundestag, 2002).

${ }^{4}$ Section 1901b see above footnote 5; Section 1901b "Discussion to ascertain the patient's will"

(1) The physician in attendance must examine which medical treatment is indicated with regard to the patient's overall condition and prognosis. He and the custodian must discuss this measure, considering the patient's will as a basis for the decision to be taken pursuant to section 1901a.

(2) When ascertaining the patient's will pursuant to section 1901a (1) or the wishes with regard to treatment or the presumed will pursuant to section 1901a (2), close relatives and other persons enjoying the confidence of the person under custodianship should be afforded the opportunity to make a statement insofar as this is possible without any considerable delay.

(3) Subsections (1) and (2) apply to authorized representatives with the necessary modifications (German Bundestag, 2002). 
in the heading of its decision, that "The applying of artificial methods of providing nutrition for a patient, who is affected by serious and irreversible damages in the cerebral section and thus is unable to take nutrition without help, has to be considered as an artificial, un-natural interference in the natural process of human life, which includes the death".

The court refers to the principle "in dubio pro vitae" (in doubtful situations life prevails), which rules the treatment of persons, totally unable to articulate and to react. But the court also states, that this principle stands behind the obligation of the medical doctor in charge to inform the custodian (a lawyer) and relatives about the real situation and circumstances. In this case, the medical doctor did not perform his duty according to $\S 1901$ b Civil Code (German Bundestag, 2002); because this information would have shown the picture, that the further medical treatment will only continue the painful life and will not change the fact that the patient will die soon. Therefore, the continuation of this very life has to be qualified as a damage according to section 249 Civil Code $^{5}$. The court underlines that this question has not been raised in domestic jurisdiction until now. The assessment as a damage is not a statement on the value of life; because this very situation is characterized by the unnatural interference in life; and life includes the fact of death. Such life is in comparison with an ended life a damage, because the artificial nutrition is an illegal interference with the effect, that the patient had to continue his painful life. Therefore, the medical doctor was obliged to pay compensation.

The medical doctor requested a review of this decision by the Federal Court of Justice.

\section{Civil Law regulations according to the German Civil Code}

It is supposed to be differentiated between non-pecuniary damage in connection to life support ( $\S 253$ par. 2 Civil $\operatorname{Code}^{6}$ ) and pecuniary damage concerning treatment and care costs in this period.

Non-pecuniary damages are the most controversial issue. The reason for that are difficulties in establishing that such damage exists as well as in an assessment of the amount of it. In Germany compensation of non-pecuniary damage is restricted by law. Money may be demanded in compensation for any damage that is not pecuniary loss only in the cases stipulated by law.

In German law non-pecuniary damages are called "Immaterieller Schadensersatz" (nonmaterial damage) or "Schmerzensgeld" (compensation for pain and suffering). § 253 Civil

5 Section 249 "Nature and extent of damages"

(1) A person who is liable in damages must restore the position that would exist if the circumstance obliging him to pay damages had not occurred.

(2) Where damages are payable for injury to a person or damage to a thing, the obligee may demand the required monetary amount in lieu of restoration. When a thing is damaged, the monetary amount required under sentence 1 only includes value-added tax if and to the extent that it is actually incurred (German Bundestag, 2002).

6 Section 253 "Intangible damage"

(1) Money may be demanded in compensation for any damage that is not pecuniary loss only in the cases stipulated by law.

(2) If damages are to be paid for an injury to body, health, freedom or sexual self-determination, reasonable compensation in money may also be demanded for any damage that is not pecuniary loss (German Bundestag, 2002). 
Code refrained from including the term "Schmerzensgeld" in the norm; nevertheless, this term become widely established in German law (Münchener Kommentar..., 2019: § 253 Rn. 4).

There is lack of notion of non-pecuniary damage in German Civil Code. The Civil Code does not contain a definition of non-pecuniary damage. Non-pecuniary damage is such damage, which is not material ones (Brox, Walker, 2010: 576). This definition is quiet narrow.

According to $\S 253$ par. 1 Civil Code non-pecuniary damages covers those damages which are not pecuniary damages. It means loss of physical and emotional well-being (Brox, Walker, 2010: 576). It covers, for example, pain and suffering, pains, injured feelings (Magnus, 2003: 5 ) as well as fears, grief, and restriction of the feel of life (Brox, Walker, 2010).

$\S 253$ par. 2 Civil Code states that non-pecuniary damage may be compensated in case of an "injury to body, health, freedom or sexual self-determination" (German Bundestag, 2002).

It is necessary to notice that earlier almost the same provisions contained in $\S 847$ Civil Code older version. The former $\S 847$ Civil Code was located in chapter dealing with tort law. It means that non-pecuniary damage concerned only tort law liability (delict). The old $\S 847$ Civil Code has been abolished and replaced by a new provision of general application (new $\S 253$ par. 2 Civil Code) (Magnus, 2003). The transfer of this provision has significantly increased its range of application. The new $\S 253$ par. 2 Civil Code is located in the general part of the Law of Obligations. Thus, they are generally applicable irrespective whether liability is based on tort, contract, or strict liability (Magnus, 2003: 5-6; Looschelders, 2013: 517; Medicus, 2005: 245; Münchener Kommentar..., 2019: $\S 253$ Rn. 2). That means that the plaintiff had grounds to claim non-pecuniary damage.

According to prevailing opinions in German civil law, non-pecuniary damages have two functions: On the one hand, it should compensate loss of well-being; on the other hand, it should carry out function of satisfaction (Brox, Walker, 2010). In addition, "Schmerzensgeld" is partially assigned the task to prevent intervention in legally protected rights referred to in $\S 253$ par. 2 Civil Code (Münchener Kommentar..., 2019). In this case, the focus is on compensation of non-pecuniary damage, so that a preventive effect of the compensation is at most a desirable side effect (Münchener Kommentar..., 2019).

The right to compensation for immaterial damage arises with that for compensation obligating event. Therefore, it is transferred to the heirs (legal successor) by law, without of any declaration of will. The right to claim passes to the heirs, even if the deceased injured person has previously neither submitted a claim nor expressed the will to do so (Münchener Kommentar..., 2019).

The higher regional court - OLG München stated that a claim for compensation of nonpecuniary damage is as opposed to a claim for monetary compensation for violation of the right of personality, after the abolition of $\S 847$ par. 1 sentence 2 Civil Code older version is also heritable without limitation (Higher Regional Court of Munich, 2017).

The main issue is an assessment of an amount of compensation. The difficulties exist because it is actually impossible to calculate a money equivalent of pain, suffering, stress, disasters etc.

The plaintiff claims compensation for non-pecuniary damage and measures it in an amount of at least $100000 €$. He grounded above mentioned amount on reasons that 
in connection with artificial nutrition via PEG (percutaneous endoscopic gastrostomy) tube for 22 months there was continued bodily harm to his farther. As a result, the farther had to cope with "continuing illness" as well as with related to it "pain and suffering" (District Court Munich I, 2017).

The higher regional court - OLG München considered the non-pecuniary damage compensation as justified. By measuring the amount of non-pecuniary damage, it should be considered that "bedridden" patient has had to endure "enormous health impairments over a period of approximately 21 months until death". Thus, higher regional court OLG München awarded non-pecuniary damage compensation in the amount of $40000 €$ (Higher Regional Court of Munich, 2017).

The Federal Court of Justice in his judgement of 02.04.2019 emphasizes that not every damage could be recognized by legal order. With regard to Art. 1 par. 1, 2 par. 1 of the Basic Law this would not be the case with continued survival as a result of artificial nutrition: "Human life is the highest ranked legally protected right and absolutely worth preserving. Any third party is entitled to judge the value of it. Therefore, it is not possible to consider the life as damage. Even if it is about to live with suffering" (Federal Court of Justice, 2019).

Consequently, a claim for non-pecuniary damage cannot be derived from the survival of a patient made possible by life-sustaining measures (Federal Court of Justice, 2019).

\section{The Federal Court of Justice's decision - extracts}

" $<\ldots>$ Because no immaterial damage can be identified (253 par. 2 Civil $\mathrm{Code}^{7}$ ).

a) For the assessment of a damage it is necessary to compare the existing situation with the - hypothetical - situation, if the damaging event would not have taken place. A possible disadvantage, which is the result of this comparison is a damage only in the case, that the legal system acknowledges this as a damage $<\ldots>$.

b) This acknowledgement is missing in this case. Here stands on the one side the prolongation of a life, affected with illness, through medical treatment, on the other side stands the - hypothetical - situation characterized with the ending of the medical treatment, that means the death. The life of a human being is the highest value in the legal system and thus has to be pertained. Nobody has the right to assess a life. Therefore, it is not permitted, to qualify a life, even if this life affected with serious illness, as a damage, (art. 1 chap. 1, art. 2 chap. 2 sentence 1 Basic Law of the Federal Republic of Germany ${ }^{8}$ ).

\section{Section 253 "Intangible damage"}

(1) .... .

(2) If damages are to be paid for an injury to body, health, freedom or sexual self-determination, reasonable compensation in money may also be demanded for any damage that is not pecuniary loss (German Bundestag, 2002).

${ }^{8}$ Article 1 "Human dignity - Human rights - Legally binding force of basic rights"

(1) Human dignity shall be inviolable. To respect and protect it shall be the duty of all state authority.

Article 2 "Personal freedoms"

1) Every person shall have the right to free development of his personality insofar as he does not violate the rights of others or offend against the constitutional order or the moral law.

(2) Every person shall have the right to life and physical integrity. Freedom of the person shall be inviolable. These rights may be interfered with only pursuant to a law (German Bundestag, 1949). 
aa) In the so called "rubella case", where the medical doctor in charge did not see the pregnant woman's infection with rubella which led to the decision not the perform an (legal) abortion with the consequence, that the child was born with serious defects, the (Court's) senate refused to accept the child's right to compensation. It is impossible to assess on a general level, whether life with serious disablement (wrongful life) is a damage in comparison with not-living or whether it is still the better situation. A legally binding assessment on the value and purpose of another person's life is not permitted for good reasons. A human being has to bear his/her life as it is designed by nature.

According to the judgment of the $2^{\text {nd }}$ Senate of the Federal Constitutional Court from May $28^{\text {th }} 1993$ (failed abortion), the Constitution (article 1 par. 1 Basic Law of the Federal Republic Germany) imposes a verdict to qualify the existence of a child as a source of damage (Federal Constitutional Court, 1993: 296). All branches of power are obliged to respect every human being because it exists. The Senate underlined in his reaction on this fact, that according to his assessment, it is forbidden to qualify the existence of a child as a damage.

bb) The higher regional Court of appeal was right, refusing to apply all considerations of the judgment of the Senate on the "rubella case" on the current procedure. The difference is as follows: In the former case, the issue was, that a life, affected with pain was not prohibited by an abortion, but in the current case the issue is the continuation of a painful life which has not been ended by a stop of medical treatment. These two cases are different especially in the very aspect, that a human has the right to decide autonomously about the question on medical treatment as well on stopping treatment which supports the continuation of life; such right is not adherent to a nasciturus. But this distinction has not the logical consequence, that the continued painful life has to be qualified as a damage.

(1) Today, the process of dying shows a growing dependence of medical innovations and is not any longer exclusively the result of fate - but the result of men's influence. From the Constitutional verdict, to consider a human being as an object but as the subject of medical treatment, follows the conclusion that a patient has during all phases of his/her life the right to decide sovereignly whether he/she wants to undergo medical treatment. $<\ldots>$ Therefore, also after to development of the situation to the state, when a personal will cannot be expressed any longer, the earlier voiced will or assumed will of the patient is relevant for the decision, whether medical treatment for the continuation of life shall be continued or stopped. Shows the will the direction to stop treatment and to allow to die, a right on refusal and protection against further treatment is established. In such situation, the obligation of the state to protect life according to article 2 par. 2 Basic Law of the Federal Republic of Germany ${ }^{9}$ has to step behind the right of a sovereign decision of the patient, even if there would have been a chance of successful treatment and perspective for life under further treatment.

\section{${ }^{9}$ Article 2 "Personal freedoms"}

(1) .... .

(2) Every person shall have the right to life and physical integrity. Freedom of the person shall be inviolable. These rights may be interfered with only pursuant to a law (German Bundestag, 1949). 
(2) But in any case the continuation of life and the further pain cannot be qualified as a damage in the current case. Even, if the patient considers his/her life as not worth to live, the overall rule of the Constitution forbids all branches of state's powers, including the judiciary, to make such a judgment on the life of the patient with the conclusion, such life is a damage. Even, if the will of the patient is realized and such his/her life terminated, still rules the above mentioned Constitutional verdict to qualify such life as damage, if this life is not terminated. In any case, it is beyond of human insight, if a life, affected with pain is a disadvantage in comparison to a terminated life.

The illness, which affects the life, which continues due to the medical treatment cannot be isolated from the life and considered as a damage, because it cannot be separated from life - as it is the case in the sphere of the maintenance obligations of parents towards children" (Federal Court of Justice, 2019).

\section{The qualification according to Ukrainian Law}

\subsection{The dimension of Constitutional law}

This case concerned the (inherited) right to request compensation of a patient against the medical doctor, that means it is a question, based purely on civil law. But the civil court referred to the Constitution when qualifying the damage: is life a damage? In this case, the question was not the patient's protection through the right of life and health, the issue was the application of a value, stated by the Constitution. This value used the court for the answer, whether life is a damage.

This leads to the question, how such value is established and via which legal mechanism he is applied for the qualification of an issue of civil law. As already stated, this topic shall be described on the background of the Constitution of Ukraine, because the relevant aspects of constitutional law can be applied in Ukrainian constitutional law in the same way as in German constitutional law.

The Constitution of Ukraine has a general chapter and the second chapter containing the rights and freedoms. These rights and freedoms have the function, to provide a space of freedom for the citizens and people. That means they have the function to protect and to defend against the state.

In the second chapter also can be found rights, which - in whatever way - oblige the state, to do something for his citizens and people living within its borders, for example, to provide school-education. These rights and freedoms have the function, to enable citizens and people to participate within the society or to receive support, which at the end - enables also to participate in the common life in an adequate manner. Finally, there are rights and freedoms, which guaranty the possibility to participate in the state's and municipality's organization, for example, article 38 and the right to vote.

All these rights and freedoms have in common, that they are efficient in the relations between state and people and citizens.

These rights and freedoms fulfil another additional function: they form an objective system of values. The rights and freedoms form the perception, how the citizens and people shall live and shall be able to live on Ukrainian territory. To complete this system, it is necessary to include article 3 , where the Constitution expressively contains the word "value". This system of values exists separate from the special rights and freedoms in the second chapter, it is a system of values on the level of the law of the Constitution. 
That means, this system is law of the Constitution and thus must be applied and respected according to articles 8 par. 2, 6 par. 2, and 19 par. 2 of the Constitution, the values share all effects of articles 8 par. 2, 6 par. 2, and 19 par. 2 (Constitutional Court of Ukraine, 2018). In other words, laws must be applied in the light of this system of values.

The mechanism of the application is clear: it is Constitutional law, which binds all branches of power; the courts is one of the branches. In case, that a court applies law, it must respect and apply this system of values. Therefore, a civil court may not qualify the fact, that a human must live as damage as regulated in civil laws.

If a person considers his/her life as a damage or an unbearable burden, then it is the person's right to make this qualification and if the person draws consequences he/she is in most of western countries protected by the person's basic freedom.

\subsection{Civil law}

The main issue to be considered is non-pecuniary damage compensation.

Article 23 part 1 of the Civil Code of Ukraine contains a general principle allowing compensation of non-pecuniary damage in any case of violation of rights (Verkhovna Rada of Ukraine, 2003). According to art. 23 part 2 of the Civil Code of Ukraine nonpecuniary damage covers inter alia physical pain and suffering caused by health injury as well as mental suffering caused by wrongful action. The conditions for the compensation of non-pecuniary damage are prescribed in details in art. 1167-1168 etc.

It is evident that the legal systems of both countries recognize the possibility to compensate non-pecuniary damage. However, Ukrainian law differs from German law with respect to range of application of non-pecuniary damage. Non-pecuniary damage under German could be compensated in cases limited by law, whereas under Ukrainian law in any case of violation of rights.

It could be assumed that, hypothetically, the plaintiff could be awarded nonpecuniary damage. The amount of damage would be considerably lower. Furthermore, the probability of such lawsuits in Ukraine is quite low.

In light of these circumstances, the following arguments shall be proposed for the further considerations on such claims for compensation:

- it is difficult to image such lawsuits in Ukraine, because of both culture and legal differences; but the circumstances and the understanding of the rights of persons in medical treatment may change;

- comparative analysis of damage compensation according to both national civil laws requires a separate research;

- the issue of inheritance law is considerably different. An heir cannot inherit a right to claim compensation of non-pecuniary damage. The heir succeeds the right to nonpecuniary damage only in case when compensation was awarded by court to the testator inter vivos (prior the death of testator) (art. 1230 of Civil Code of Ukraine). That means, according to Ukrainian law the right exists only, if a court has stated this right; not from the moment, when the damage occurred;

- in any way, the different regulation of inheritance law makes it impossible, to raise such claim under Ukrainian law. Civil Code of Ukraine require that a court decided on the existing of such a right; that mean, the possibilities in Ukrainian civil law are much narrower. 


\section{Conclusions}

The comparative presentation on Constitutional law shows parallels on the level of the functions of rights and freedoms in a Constitution: they have the function to protect the individual against the interference of the State. But the rights and freedoms also create a system of values on the level of constitutional law which has to be considered in all spheres of national law - also in relations between private persons ruled by civil law. These functions are a traditional element of German Constitutional law and of Ukrainian Constitutional law according to the recent jurisdiction of the Constitutional Court of Ukraine.

A different picture shows the comparison of both civil law systems: The German civil law is more open for non-pecuniary and pecuniary damage compensation claims due to a differentiated understanding of the role and rights of an individual, which realizes the understanding of human dignity according to art. 1 of the Basic Law of Germany. The Ukrainian civil law provides on the one side a wider scope of non-pecuniary damage compensation, on the other side, the possibility to realize inherited rights is less wide as under German Civil law.

Taking into consideration the development of such rights and claims under German civil law, the picture shows a growing sensibility towards these questions; such development is therefore a logically development under Ukrainian civil law, as it is under the influence of Ukrainian Constitutional law.

\section{Bibliography:}

1. Grundgesetz für die Bundesrepublik Deutschland (GG), Ausfertigungsdatum 23.05.1949 / Deutscher Bundestag. URL: https://www.gesetze-im-internet.de/gg/BJNR000010949.html.

2. Brox H., Walker W. Besonderes Schuldrecht. 34. Auflage. München : C.H. Beck, 2010. $772 \mathrm{~S}$.

3. Цивільний кодекс України : Закон України від 16 січня 2003 р. № 435-IV / Верховна Рада України. Відомості Верховної Ради України. 2003. № 40-44. Ст. 356.

4. Конституція України : Закон України від 28 червня 1996 р. № 254к/96-ВР / Верховна Рада України. Відомості Верховної Ради України. 1996. № 30. Ст. 141.

5. Рішення Конституційного Суду України у справі за конституційним поданням Уповноваженого Верховної Ради України з прав людини щодо відповідності Конституції України (конституційності) окремих положень частини другої статті 8, другого речення частини четвертої статті 16 Закону України «Про звернення громадян» (справа про звернення осіб, визнаних судом недієздатними) від 11 жовтня 2018 р. № 8-p/2018. URL: http://www.ccu.gov.ua/sites/default/files/docs/8_r_2018.pdf.

6. Abortion (Schwangerschaftsabbruch II) : Entscheidung des Bundesverfassungsgerichts vom 28. Mai 1993 / Bundesverfassungsgericht. BVerfGE 88, 203. URL: https://germanlawarchive. iuscomp.org/?p=1190.

7. Urteil in dem Rechtsstreit vom 2. April 2019 № VI ZR 13/18 / Bundesgerichtshof. URL: http://juris.bundesgerichtshof.de/cgi-bin/rechtsprechung/document.py?Gericht=bgh\&Art=en\&D atum $=2019-4 \&$ Seite $=7 \& n r=95016 \&$ pos $=239 \&$ anz $=249$.

8. Bürgerliches Gesetzbuch (BGB) vom 2. Januar 2002 / Deutscher Bundestag. URL: https://www.gesetze-im-internet.de/bgb/.

9. Haftung des behandelnden Arztes bei unterbliebenem Abbruch der künstlichen Ernährung am Lebensende : Endurteil v. 18.01.2017 - 9 O 5246/14 / LG München I. URL: https://www.gesetze-bayern.de/Content/Document/Y-300-Z-BECKRS-B-2017-N-112362. 
10. Looschelders D. Schuldrecht: Besonderer Teil. 8. Auflage. München : Vahlen, 2013. $500 \mathrm{~S}$.

11. Magnus U. The Reform of German Tort Law. Barcelona, 2003. 11 p. URL: http://www.dl.edi-info.ir/The\%20Reform\%20of\%20German\%20Tort\%20Law.pdf.

12. Medicus D. Schuldrecht I: Allgemeiner Teil. 16. Auflage. München : C.H. Beck, 2005. $480 \mathrm{~S}$.

13. Münchener Kommentar zum Bürgerlichen Gesetzbuch: BGB. Band 2 : Schuldrecht Allgemeiner Teil I (§§ 241-310). 8. Auflage. München : C.H. Beck, 2019. 1828 S.

14. Arzthaftungsrecht: Behandlungsabbruch bei schwerstkrankem Patienten (hier PEGSonde) : Endurteil v. 21.12.2017 - 1 U 454/17 / OLG München. URL: https://www.gesetzebayern.de/Content/Document/Y-300-Z-BECKRS-B-2017-N-146433.

\section{References:}

1. German Bundestag (1949). Grundgesetz für die Bundesrepublik Deutschland (GG) [Basic Law for the Federal Republic of Germany (GG)] on 23.05.1949. Retrieved from: https://www.gesetze-im-internet.de/gg/BJNR000010949.html [in German].

2. Brox, H., Walker, W. (2010). Besonderes Schuldrecht [Special liability law]. 34th ed. München: C.H. Beck [in German].

3. Verkhovna Rada of Ukraine (2003). Tsyvilnyi kodeks Ukrainy: Zakon Ukrainy vid 16 sichnia 2003 r. № 435-IV [Civil Code of Ukraine: Law of Ukraine of January 16, 2003. № 435-IV]. Vidomosti Verkhovnoi Rady Ukrainy, no. 40-44, art. 356 [in Ukrainian].

4. Verkhovna Rada of Ukraine (1996). Konstytutsiia Ukrainy: Zakon Ukrainy vid 28 chervnia 1996 r. № 254к/96-BP [Constitution of Ukraine: Law of Ukraine of June 28, 1996. № 254к/96-BP]. Vidomosti Verkhovnoi Rady Ukrainy, no. 30, art. 141 [in Ukrainian].

5. Constitutional Court of Ukraine (2018). Rishennia Konstytutsiinoho Sudu Ukrainy u spravi za konstytutsiinym podanniam Upovnovazhenoho Verkhovnoi Rady Ukrainy z prav liudyny shchodo vidpovidnosti Konstytutsii Ukrainy (konstytutsiinosti) okremykh polozhen chastyny druhoi statti 8, druhoho rechennia chastyny chetvertoi statti 16 Zakonu Ukrainy "Pro zvernennia hromadian" (sprava pro zvernennia osib, vyznanykh sudom nediiezdatnymy) vid 11 zhovtnia 2018 r. № 8-p/2018 [Decision of the Constitutional Court of Ukraine in the case on the constitutional submission of the Commissioner for Human Rights regarding the conformity of the Constitution of Ukraine (constitutionality) with the separate provisions of part two of Article 8, second sentence of part four of Article 16 of the Law of Ukraine "On Citizens' Appeals" (case of applications of persons recognized court of incompetence) dated October 11, 2018 № 8-p/2018]. Retrieved from: http://www.ccu.gov.ua/sites/default/files/docs/8_r_2018.pdf [in Ukrainian].

6. Federal Constitutional Court (1993). Abortion (Schwangerschaftsabbruch II): Entscheidung des Bundesverfassungsgerichts vom 28. Mai 1993 [Abortion (termination of pregnancy II): Decision of the Federal Constitutional Court of May 28, 1993]. BVerfGE 88, 203. Retrieved from: https://germanlawarchive.iuscomp.org/?p=1190 [in German].

7. Federal Court of Justice (2019). Urteil in dem Rechtsstreit vom 2. April 2019 № VI ZR 13/18 [Judgment in the case of 2 April 2019 № VI ZR 13/18]. Retrieved from: http://juris.bundesgerichtshof.de/cgi-bin/rechtsprechung/document.py?Gericht=bgh\&Art=en\&D atum $=2019-4 \&$ Seite $=7 \&$ nr=95016\&pos $=239 \&$ anz $=249$ [in German].

8. German Bundestag (2002). Bürgerliches Gesetzbuch (BGB) vom 2. Januar 2002 [German Civil Code (BGB) of January 2, 2002]. Retrieved from: https://www.gesetze-im-internet.de/bgb/ [in German].

9. District Court Munich I (2017). Haftung des behandelnden Arztes bei unterbliebenem Abbruch der künstlichen Ernährung am Lebensende: Endurteil v. 18.01.2017 - 9 O 5246/14 
[Liability of the treating doctor in the event of failure to terminate the artificial diet at the end of life: final judgment of 18 January 2017, 9 O 5246/14]. Retrieved from: https://www.gesetzebayern.de/Content/Document/Y-300-Z-BECKRS-B-2017-N-112362 [in German].

10. Looschelders, D. (2013). Schuldrecht: Besonderer Teil [Obligation law: special part]. 8th ed. München: Vahlen [in German].

11. Magnus, U. (2003). The Reform of German Tort Law. Barcelona. Retrieved from: http://www.dl.edi-info.ir/The\%20Reform\%20of\%20German\%20Tort\%20Law.pdf [in English].

12. Medicus, D. (2005). Schuldrecht I: Allgemeiner Teil [Obligation I: General Part]. 16th ed. München: C.H. Beck [in German].

13. (2019). Münchener Kommentar zum Bürgerlichen Gesetzbuch: BGB. Band 2: Schuldrecht Allgemeiner Teil I ( $\S ~ 241-310)$ [Munich comment on the Civil Code: BGB. Volume 2: Obligation Law General Part I (Sections 241-310)]. 8th ed. München: C.H. Beck [in German].

14. Higher Regional Court of Munich (2017). Arzthaftungsrecht: Behandlungsabbruch bei schwerstkrankem Patienten (hier PEG-Sonde): Endurteil v. 21.12.2017 - 1 U 454/17 [Medical Liability Law: Discontinuation of treatment for seriously ill patients (here PEG probe): final judgment of 21 December 2017, 1 U 454/17]. Retrieved from: https://www.gesetze-bayern.de/ Content/Document/Y-300-Z-BECKRS-B-2017-N-146433 [in German].

\title{
ЖИТТЯ ЯК ШКОДА: КОМПЕНСАЦІЯ МОРАЛЬНОЇ ШКОДИ ЗА ПРОДОВЖЕННЯ ЖИТТЯ (ТЛУМАЧЕННЯ ЦИВІЛЬНОГО ПРАВА У СВІТЛІ КОНСТИТУЦЇ̈)
}

\author{
Катерина Кравченко, \\ юрист І-ї категорії \\ юридичного факультету \\ Київського національного університету імені Тараса Шевченка \\ legal_@i.ua \\ Бернгард Шлоер, \\ доцент кафедри адміністративного права \\ юридичного факультету Центру німецького права \\ Київського національного університету імені Тараса Шевченка, \\ доктор юридичних наук (нім.) \\ vewrmuc@gmail.com
}

У статті аналізується рішення Федерального верховного суду Федеративної Республіки Німеччина, яке стосується питання про те, чи може життя розглядатися як икода, щяо дає право на компенсацію моральної та матеріальної шкоди. Справа стосується особи, яка за станом здоров'я не могла спілкуватися, а отже, висловити свою волю щодо подальшого життя. Особі за допомогою медичного лікування було продовжено життя, незважаючи на те, щуо вказана особа була важкохворою, а лікування лише на певний час відкладало неминучу смерть. Суд, вирішуючи питання про те, чи може життя розглядатися як икода в цивільному праві, звернувся до норм Конституиії Федеративної Республіки Німеччина.

Стаття містить аналіз рішення Федерального верховного суду Федеративної Республіки Німеччина, рімення судів попередніх інстанцій, а також порівняльно-правові аспекти німецького та украӥнського права.

Мета статті - презентувати рішення Федерального верховного суду Федеративної Республіки Німеччина, яке, за визначенням самого суду, є безпрецедентним. Узв 'язку з тим, щио ситуація, на 
підставі якої було подано позов, не має начіональних меж, варто представити иую тему також на розгляд професійної публіки за межами Німеччини.

Основним методом, застосованим у розглядуваній статті, є метод порівняльного аналізу конституиійного та иивільного права.

Логічно, щзо результатом представлення рішення суду та порівняльних правових підстав $\epsilon$ інформація для подальших дискусій. Незважаючи на це, порівняльний аналіз показує паралельність рівня функиіонування прав і свобод у Конституції Німеччини. Варто зазначити, щуо права й свободи також створюють систему иінностей на рівні конституційного права, яка повинна братися до уваги в усіх сферах національного права, зокрема й у відносинах між приватними особами, щчо регулюються циивільним правом.

Ключові слова: життя як шкода, право на життя, компенсація моральної шкоди, матеріальна шкоди, відповідальність лікарів, договір на надання медичних послуг. 